\title{
Gregarine Parasite Belonging to the Family Diplocystidae Bhatia, 1938 Reported from the Cockroaches Blatta orientalis (Dictyopetra: Blattidae) from Kashmir
}

\section{Rehana R, Bhagat RC, Fayaz A Rukhsana and Tanveer A Sofi*}

Department of Zoology, University of Kashmir, Srinagar, Jammu and Kashmir, India

\begin{abstract}
During the present study Diplocystis kasmirensis n. sp. (Sporozoa: Eugregarinida) were collected from Haemocoel including gut surface of Blatta orientalis Linnaeus (Dictyoptera; Blattidae) with description to their morphology, life cycle stages and taxonomy.
\end{abstract}

Keywords: Protozoan; Cockroach; Camera lucida; Srinagar; India

\section{Introduction}

Protozoan diseases of insects are ubiquitous and comprise an important regulatory role in insect populations $[1,2]$. The main route of infection by protozoans in insects is through mouth, however in some cases transmission may be through egg of host (trans ovum). One important and common consequence of protozoan infection is a reduction in the number of offspring produced by infected insects.

Although protozoan pathogens play a significant role in the natural limitation of insect populations. Involved protozoan species have successfully been utilized for suppression of insect pests of agricultural, horticultural, forestry, medical and veterinary importance in different parts of the world [3].

Gregarines were first found in cockroaches by Siebold. Most gregarines have been found in the midgut but Protomagalhaensia serpentula and Diplocystis sp. [3] also have been reported from the body cavity [4].

\section{Materials and Methods}

The cockroaches for the present study were collected at night with the help of forceps from toilet, main holes' bathroom from different localities of Srinagar, and were then dissected with the help of scissors, forceps and needles and the alimentary tract was drawn out intact by grasping the head and thorax and gently pulling apart.

The field collected Insects were anesthetized with chloroform or by putting them in a refrigerator for 5-10 minutes [5]. The anterior and posterior extremities of the host were clipped off as close to the ends of the insect as possible with scissors, forceps and needles and the alimentary tract was drawn out intact with the help of forceps, by grasping the head and thorax and gently pulling apart. The intestine came out attached to the head. It was then slit lengthwise with fine needles, placed flat on a slide, and the masses of food were then teased out carefully to form a layer as thin, nearly transparent as possible and scanned for protozoan parasites. At the same time the Malpighian tubules, fat bodies, other tissues and body cavity was also scanned for the protozoans. The protozoan parasites were first observed unfixed in live condition [6].

The number of hosts and protozoan parasites collected from them were recorded and placed in sampling bottles till further processing. After examining protozoans in live condition, they were processed for permanent slide preparations for detailed microscopic examination and identification [7]
Thin smear of host intestine, Malpighian tubules and body fluid was prepared on a clean slide or cover slip and was dropped face down into a petri-dish of fixative. The slide or cover slip was allowed to float on the surface with no air bubbles. This held the specimens against the glass until they were affixed through fixation of parasites. In each case, material on cover slips was allowed to fix for at least 5 minutes. After fixing in AFA solution the parasites were stained with Semichon's Acid and finally dehydrated and mounted in DPX to get the correct picture of protozoan parasites [8-10].

\section{Key to the Families of Order Eugregarinida}

1. Mature trophozoites with primary segmentation only (distinguishing the protomerite and deutomerite); no secondary segmentation is present.

2. Mature trophozoites with secondary segmentation of the protomerite and deutomerite - Metameridae.

3. Epimerite simple, not dilated into a lobate sucker.

4. Epimerite dilated into a lobate sucker.

5. Gametocysts dehisce by simple rupture - Cephaloidophoridae.

6. Gametocysts dehisce through one or more sporoducts.

7. Epimerite apparently, an extension of protomerite, without distinct neck or stalk; parasitic in crustacean -Cephalobidae.

8. Epimerite without four distinct cup-like suckers and a distinct neck; parasitic in insects - Hermocystidae.

9. Gametocysts with single sporoduct - Didymophyidae.

10. Gametocysts with more than one sporoduct - Gregarinidae.

*Corresponding author: Tanveer A Sofi, Department of Zoology, University of Kashmir, Srinagar-190 006, Jammu and Kashmir, India, Tel: +919797127214 E-mail: stanveer96@gmail.com

Received October 07, 2016; Accepted November 11, 2016; Published Novembe 15, 2016

Citation: Rehana R, Bhagat RC, Rukhsana AF, Sofi TA (2016) Gregarine Parasite Belonging to the Family Diplocystidae Bhatia, 1938 Reported from the Cockroaches Blatta orientalis (Dictyopetra: Blattidae) from Kashmir. J Vet Sci Technol 7: 399. doi: 10.4172/2157-7579.1000399

Copyright: @ 2016 Rehana R, et al. This is an open-access article distributed unde the terms of the Creative Commons Attribution License, which permits unrestricted use, distribution, and reproduction in any medium, provided the original author and source are credited. 
Citation: Rehana R, Bhagat RC, Rukhsana AF, Sofi TA (2016) Gregarine Parasite Belonging to the Family Diplocystidae Bhatia, 1938 Reported from the Cockroaches Blatta orientalis (Dictyopetra: Blattidae) from Kashmir. J Vet Sci Technol 7: 399. doi: 10.4172/2157-7579.1000399

Page 2 of 3

11. Epimerite apparent in mature trophozoites, complex or at least strongly differentiated.

12. Epimerite in mature trophozoites absent, vestigial, invaginated or reduced to a small cap or spherule.

13. Epimerite in mature trophozoites absent or reduced and invaginated; oocysts ovoidal or ellipsoidal with or without equatorial suture - Stenophoridae.

14. Epimerite in mature trophozoites reduced to a small cap or spherule; oocyst ellipsoidal - Cnemidosporidae.

15. Epimerite with bristle or epicytic processes - Brustiophoridae.

16. Epimerite varied, if present epicytic processes strong, digitate or hooked; not bristle-like.

17. Oocysts biconical, cylindric conical, crescentic or irregular, liberated singly or in clumps, but not in chains; gametocyst with or without secondary cyst wall when present usually lose and gelatinous - Actinocephalidae.

18. Oocysts pruse-shaped or hat-shaped, emitted in chains; gametocyst with loose, rugose, secondary cyst wall Stylocephalidae.

19. Trophozoites solitary or associated in pairs and spores are ovoid to spherical - Diplocystidae.

20. Trophozoites range from spheroid to much elongated type and spores are typically spindle shaped - Monocystidae.

\section{Diagnostic characters of the family Diplocystidae}

Coelomic or gut parasites of insects; trophozoites solitary or associated in pairs; spores round or oval, with eight sporozoites. Syzygy is precocious with fusion of the gamonts. The oocysts are ellipsoidal.

Diagnostic characters of genus Diplocystis: Trophozoites spherical to oval. Association of two individuals begin early in spherical form, spores round or oval with eight sporozoites.

\section{Diplocystis kasmirensis n. sp.}

Host: Blatta orientalis Linnaeus (Dictyoptera; Blattidae)

Site of infection: Throughout Haemocoel including gut surface

\section{Locality: Srinagar}

Out of 12 host specimens, four host specimens of Blatta orientalis, were found to be infected throughout the haemocoel including gut surface.

\section{Description}

The sporadins (Figures 1a-1c) are rounded to ovoidal, nucleus spherical with one karyosome measuring $15.375 \mu$. The cytoplasm was finely granulated. Sporadin measuring $51.25 \mu$ in diameter. They were biassociative (Figures 1d and 1e) and in apposition head to head; obese with no protomerite. The association measures $112.75 \mu$ in length and $61.65 \mu$ in width. The associated gamonts vary in size [11].

The cysts (Figure 1f) are spherical, measuring $97.75 \mu$ in diameter with the sporulation being partial. There are certain spaces on the wall which are meant for the emergence of the sporoducts. Only one sporoduct is visible. Spores (Figures 1g-1i) oval measuring $10.25 \mu$ in diameter.

\section{Discussion}

The critical examination of the present species revealed that certain important features such as the spherical trophozoites without the protomerite, the associated sporadins, the oval spores led to its placement in the genus Diplocystis Kunstler [12]

While comparing the present specimens with Diplocystis schneideri Kunstler, [4] collected from the posterior half of mid gut surface of Blattella germanica and Periplanata americana, the present specimen differed from it in host locality, as it was found throughout haemocoel of Blatta orientalis. The shape and size of spores also varied among both the species as round vs oval, 2.0 vs $10.25 \mu$ (Table 1 ).

Diplocystis major Cuenot was observed through out the haemocoel including gut surface and young stages were found in the gut epithelium of Gryllus spp. when present specimen was compared with D. major it differed in having different sizes and shapes of the spores, oval vs. rounded and measuring $10.25 \mu$ vs $8.0 \mu$ in diameter (Table 1) [13,14].

When compared with D. minor (Table 1) found throughout haemocoel of Gryllus sp., there was difference in the shape and size of spore of both the species as oval vs round measuring 8.0 vs $10.25 \mu$.

On comparison with Diplocystis chandigarhensis Bala [5] from Periplanata americana observed in fat bodies, the present specimens of parasites were found throughout haemocoel including gut surface. There was variation in the size of cysts and spores as $4.5 \times 2.5$ vs 10.25 $\mu$ and 50 vs $97.75 \mu[15,16]$.

Hence, all the above morphological characters and measurements discussed with the already known species of the genus Diplocystis made differences clear with the presently considered specimens [17]. Taking into account the above-mentioned differences, it became necessary to create a new species for which the name Diplocystis kasmirensis n. $\mathrm{sp}$. is proposed after the name of the study state i.e., Kashmir.

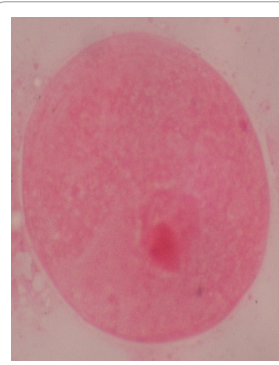

a

Figures 1a-1c: Sporadins of Diplocystis kashmirensis n. sp. 100X.

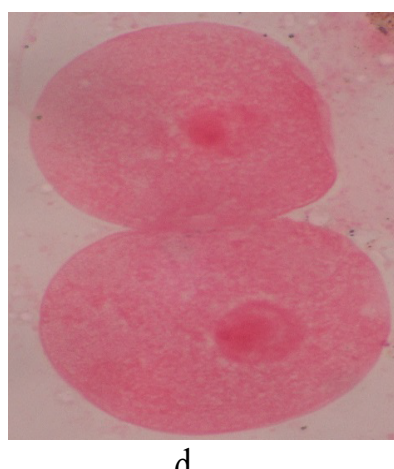

d

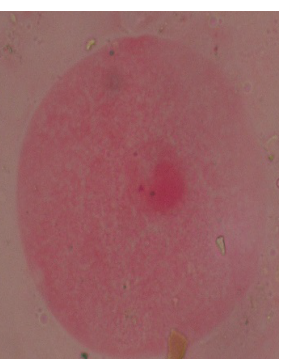

b

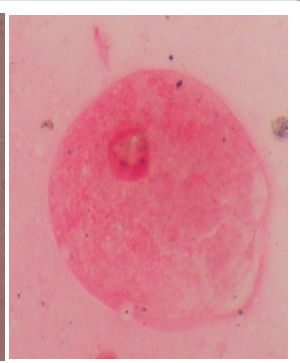

c

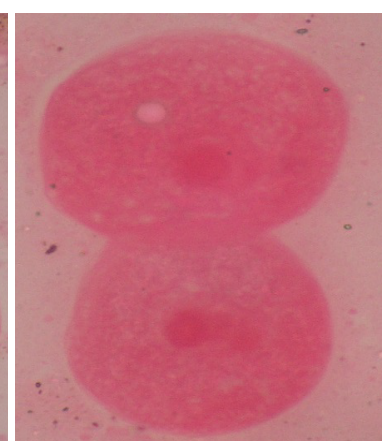

e
Figures 1d and 1e: Schizogonic stages of Diplocystis kashmirensis n. sp. 100X. 
Citation: Rehana R, Bhagat RC, Rukhsana AF, Sofi TA (2016) Gregarine Parasite Belonging to the Family Diplocystidae Bhatia, 1938 Reported from the Cockroaches Blatta orientalis (Dictyopetra: Blattidae) from Kashmir. J Vet Sci Technol 7: 399. doi: 10.4172/2157-7579.1000399

Page 3 of 3

\begin{tabular}{|c|c|c|c|c|c|c|}
\hline & & \multicolumn{5}{|c|}{ Species } \\
\hline \multicolumn{2}{|c|}{ Particulars } & \multirow{2}{*}{$\begin{array}{c}\text { Diplocystis schneideri } \\
\text { Kunstler, } 1887 \\
\text { Round-Oval }\end{array}$} & \multirow{2}{*}{$\begin{array}{c}\text { Diplocystis major Cuenot, } \\
1901 \\
\text { Oval }\end{array}$} & \multirow{2}{*}{$\begin{array}{c}\text { Diplocystis minor } \\
\text { Cuenot, } 1901 \\
\text { Oval }\end{array}$} & \multirow{2}{*}{$\begin{array}{c}\text { Diplocystis } \\
\text { chandigarhensis Bala, } \\
1988 \\
\text { Oval }\end{array}$} & \multirow{2}{*}{$\begin{array}{c}\text { Diplocystis } \\
\text { kasmirensis n. sp. } \\
\text { (Present specimen) } \\
\text { Round-Oval }\end{array}$} \\
\hline Snoro & Shape & & & & & \\
\hline spore & Size & $6.0 \mu$ & $8.0 \mu$ & $5.0 \mu$ & $4.5 \times 2.7 \mu$ & $10.25 \mu$ \\
\hline \multirow{2}{*}{ Cyst } & Shape & - & - & - & Spherical & Spherical \\
\hline & Size & - & - & - & $50 \mu$ & $97.75 \mu$ \\
\hline \multicolumn{2}{|c|}{ Host } & $\begin{array}{c}\text { Blattella germanica and } \\
\text { Periplanata americana }\end{array}$ & Gryllus sp. & Gryllus sp. & Periplanata americana & Blatta orientalis \\
\hline \multicolumn{2}{|c|}{ Site } & Mid gut surface (Post. half) & $\begin{array}{l}\text { Haemocoel including gut } \\
\text { surface and young stages } \\
\text { found in the gut epithelium }\end{array}$ & Haemocoel & Fat bodies & $\begin{array}{l}\text { Haemocoel including } \\
\text { gut surface }\end{array}$ \\
\hline
\end{tabular}

Table 1: Comparison of present specimen with four species of Diplocystis.

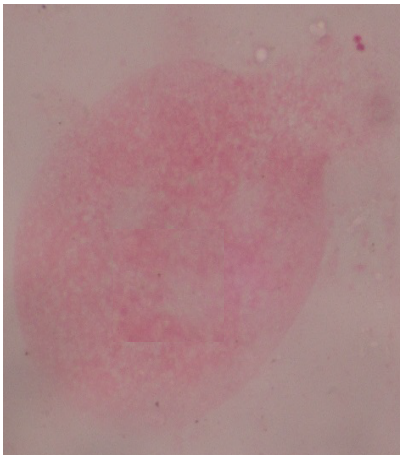

f. Cyst 100X

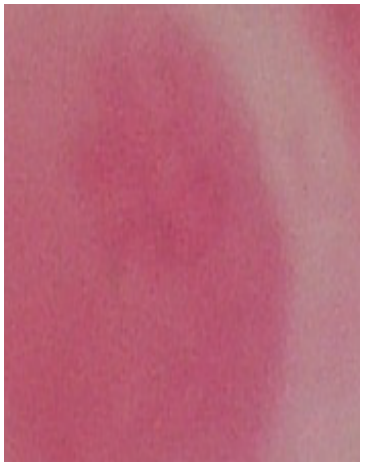

g. Spore $400 \mathrm{X}$
Figures 1f and 1g: Life cycle stages of Diplocystis kashmirensis n. sp.

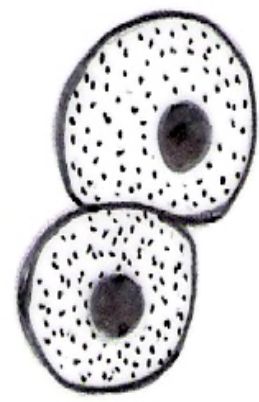

$\mathrm{h}$

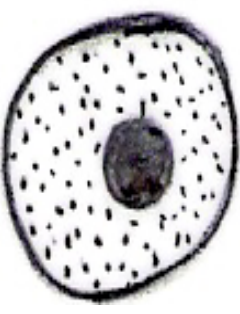

i
Figures 1h and 1i: Schizogonic and Sporadin stages of Diplocystis kashmirensis $\mathrm{n}$. $\mathrm{sp}$.

\section{References}

1. Maddox JV (1987) Protozoan diseases. In: Epizootiology of Insect Disease. Fuxa JR, Tanada Y (eds.). Wiley, New York, USA, pp: 417-452.

2. Brooks WM (1988) Entomogenous Protozoa. In: Handbook of Naturally Occurring Pesticides. Ignoffo CM (ed.). CRC Press, Boca Raton. Florida, USA, pp: 1-149.

3. Roth LM, Willis EB (1960) The biotic associations of cockroaches. Smithsonian Miscellaneous Collections 141: 1-470.

4. Kunstler MJ (1887) Diplocystis schneideri novo gen. novo sp. Tablettes Zoologiques 2: 25-66.

5. Bala P, Kaur D (1988) Gregarines found in cockroaches of the genus Periplaneta americana (Dictyoptera: Blattidae). Oikoassay 5.

6. Bishop A (1931) A Description of Embadomonas n. spp. from Blatta orientalis, Rana temporaria, Bufo vulgaris, Salamandra maculosa; with a Note upon the
"Cyst" of Trichomonas batrachorum. Parasitol 23: 286-300.

7. Cuenot L (1901) Recherches sur l'evolution et la conjugaison des gregarines. Arch Biol Paris 17: 581-650.

8. Dar GH, Bhagat RC, Khan MA (2002) Biodiversity of the Kashmir Himalaya Valley Book House.

9. Kudo R (1924) A biological and taxonomic study of the Microsporidia. Illinois Biol Monogr 9: 1-268.

10. Kudo RR (1966) Protozoology. 5th edn. Thomas CC (ed.), Springfield, Illinois, USA.

11. Kundu TK, Haldar DP (1981) Observations on two new species of cephaline gregarines (Protozoa: Sporozoa) of the genus Gregarina Dufour, 1828 from insects. Z Parasitenkd 64: 233-242.

12. Levine ND (1977) Checklist of the species of the aseptate gregarine families Aikinetocystidae, Diplocystidae, Allantocystidae, Schaudinnellidae, Ganymedidae, and Enterocystidae. J Invertebr Pathol 29: 175-181.

13. Mourya DT, Dhanda V (1981) Studies on Lankesteria sp. (Eugregarinida Diplocystidae) parasitizing Aedes albopictus (skuse). Ind J Parasitol 5: 119123.

14. Nickle WR (1972) Nematode infections. In: Textbook of insect pathology Chapter VII. Marcel Dekker Publishers, New York, USA.

15. Semans FM (1943) Protozoan parasites of the Orthoptera with special reference to those of Ohio IV. Classified list of the Protozoan parasites of the Orthoptera of the world. Classes Mastigophora, Sarcodina and Sp. Ohio J Sci 43: 221-234.

16. Sherlock PL (1973) Tipula Paludosa meigen (diptera: tipulidae): a survey of its pathogens and a study of the gregarines of the family diplocystidae. Doctoral Dissertation, University of Newcastle upon Tyne, UK.

17. Steinhaus EH (1951) Report on diagnosis of diseased insects 1944-1950. Hilgardia 20: 629-678. 